\title{
СИНТЕТИЧЕСКИЕ МОЮЩИЕ ВЕЩЕСТВА иЗ СЛАНЦЕВОЙ СМОЛЫ
}

\section{Введение}

Газосланцевая промышленность Эстонской ССР сыграла большую роль в обеспечении Северо-Запада нашей страны и в первую очередь Ленинграда жидким топливом, бытовым и промышленным газом.

В последние годы в связи с интенсивной добычей нефти, природного газа и гтроительством мощных трубопроводов роль сланцевых топливных продуктов снизилась. Более перспективным стало использование сланцевых смол для синтеза химнческих продуктов.

Здесь следует сразу же оговориться. Так как на производство химических продуктов из нефти и природного газа расходуется лишь незначительная часть ресурсов, то расчеты на недостаток в б́удущем этих сырьевых ресурсов и необходимость изыскания новых источннков углеводородного сырья, не обоснованы. Для целей химической переработки нефть и природный газ практически неисчерпаемы. Поэтому производство химических продуктов из сланцевого сырья должно быть обосновано дұугими ноказателями.

Из сланца целесообразно производить на месте такие химические продукты, привоз которых из районов с развитой нефтехимической промышленностыю затруднен и которые имеют потребителя в районе производства, а. также обладают низкой сырьевой составляющей в себестоимости готового продукта.

Перспективность синтеза поверхностно-активных веществ из сланцевой смолы объясняется следующими причинами.

1. По качеству и себестоимости сланцевые продукты не уступают аналогичным продуктам нефтехимии. Объясняется это составом легких фракций сланцевой смолы полукоксования, включающих до $50 \%$ олефиновых углеводородов преимущественно нормального строения, и составом газбензина высокотемпературного разложения горючих сланцев, содержащего до $35 \%$ бензола. После надлежащей очистки и выделения эти исходные продукты по качеству аналогичны продуктам нефтяного происхождения.

2. Перевозка поверхностно-активных веществ в виде водных растворов или паст крайне неудобна, требует специально оборудованных устройств, предохраняющих от замерзания в зимнее время, и связана с перевозкой балластной воды. Перевозка их в виде готовых порошков нецелесообразна из-за малого насыпного веса (до 0,3). При наличии крупных потребителей, каковыми являются Ленинград и Прибалтика, весь комплекс синтеза моющих средств следует производить в районе потребления.

3. В случае надобности установки для синтеза поверхностно-активных веществ могут быть переведены на другое сырье без дополнительных затрат.

В последнее десятилетие промышленность ПАВ получила большое развитие. Тем не менее еще не достаточно разработаны теоретические вопросы зависимости межлу 
структурой и свойствами отдельных представителей ПАВ. Это приводит в ряде случаев $\mathrm{K}$ неправильному оформлению технологических процессов получения некоторых ПАВ. Так, при синтезе алкиларилсульфоната (сульфонол) из олефиновых и парафиновых углеводородов получаются различные продукты. Хотя при правильной технологии сульфонол, получаемый из парафиновых углеводородов, должен обладать таким же качеством, как и сульфонол, синтезируемый из олефиновых углеводородов.

При разработке способов производства ПАВ из сланцевого сырья много внимания уделялось выяснению влияния структуры этих веществ на их свойства. Эта часть работы не связана с каким-либо конкретным источником сырья, а необходима для правильного понимания предмета и выбора условий синтеза.

Исследования по синтезу ПАВ из сланцевой смолы впервые были начаты в нашей лаборатории в 1952 году под руководством директора Института химии АН ЭССР А. Кылля. Сульфатируя суммарные компоненты сланцевой смолы, А. Қылль и Э. Кеель извлекали экстракцией сульфопродукты, состоявшие преимущественно из вторичных алкилсульфатов и сульфатированных производных нейтральных кислородных соединений $\left[{ }^{1}\right]$.

Параллельно С. Файнгольд, М. Корв и К. Валлас разрабатывали методы очисткн и выделения углеводородов для синтеза смазочных масел. Впоследствии оказалось, что выделяемые углеводороды являются хорошим нсходным сырьем для синтеза вторичных алкилсульфатов и алкиларилсульфонатов [2-4]. А. Кылль, И. Кудрявцев и В. Риккен более детально изучили технологию синтеза вторичных алкилсульфатов и разработали метод их получения, принятый в настоящее время промышленностью $\left[{ }^{5}\right]$.

С. Файнгольд, М. Корв, Т. Томсон, Г. Степанова, Х. Вооре и Р. Томсон разработали метод синтеза алкиларилсульфонатов на базе олефинов сланцевой смолы и бензола, выделяемого из газбензина камерных печей $\left[{ }^{6}\right]$. Этот метод отличается от известных в нефтехимии способов. Разработан способ выделения олефиновых углеводородов из фракций сланцевой смолы полукоксования. Сущность его заключается в последовательном проведении процессов каталитической стабилизации, сернокислотной очистки и экстракции ароматических и кислородных соединений диэтиленгликолем. По второму варианту этого способа нормальные олефиновые $\left[{ }^{7}\right]$ и парафиновые углеводороды $\left[^{8}\right]$ извлекались с помощью карбамида. Выделение олефиновых углеводородов карбамидом позволяет получать ксходные углеводороды и на их основе ПАВ с наиболее высокими показателями качества. Недостатком этого метода является малый выход углеводородов - до $30 \%$ на исходную фракцию. При незначительных масштабах производства сланцевых смол такой процесс мало перспективен.

Для усовершенствования алкилирования бензола олефинами и сульфирования алкилбензолов были проведены детальные исследования этих процессов на индивидуальных веществах. Удалось выяснить условия алкилирования, при которых происходит наименьшая изомеризация двойной связи олефиновых углеводородов [ $\left.{ }^{9}\right]$. Показано также, что глубина сульфирования зависит от вязкости сульфокислот и температуры сульфирования $\left[{ }^{10}\right]$. Исходя из этого был разработан процесс сульфирования алкилбензолов олеумом, в котором сульфирование идет вначале при температуре до $10^{\circ} \mathrm{C}$, а при увеличении вязкости сульфокислот температура повышается до $25^{\circ} \mathrm{C}\left[{ }^{11}\right]$. Эти работы, выполненные до 1962 года, послужили основой для строительства промышленного цеха синтетических моющих веществ из сланцевых смол.

Синтез алкиларилсульфонатов изучался в последние годы в целях получения продуктов с более высокой моющей способностью и лучшей биохимической окисляемостью. Для этого было проверено действие ряда катализаторов алкилирования с тем, чтобы получить фенилалканы, бензольное ядро которых расположено у крайних атомов углерода.

Для того чтобы комплекс процессов синтеза ПАВ из сланцевой смолы был экономически более выгодным, целесообразно вовлечь в переработку более низкокипя- 
щие фракции. Известно, что алкиларилсульфонаты и вторичные алкилсульфаты синтезируются на базе углеводородов выше $\mathrm{C}_{10}$. Во фракциях сланцевой смолы $\mathrm{C}_{6}-\mathrm{C}_{10}$, пока не использованных для синтеза, содержится больше углеводородов и меньше балластных ароматических сернистых соединений. Олефиновых углеводородов в названных фракциях содержится около $60 \%$; структура их имеет в основном нормальное строение. Эти углеводороды очень подходят для синтеза, так как легко очищаются от нежелательных примесей. С другой стороны, при составлении рецептур моющих средств различного назначения в смеси наряду с алкнларилсульфонатами должны нєходиться первичные алкилсульфаты. Это обусловливается синергетическим эффектом поверхностно-активных веществ. Поэтому перед нами стояла задача разработать способы синтеза первичных спиртов на базе легких фракций сланцевой смолы.

В последнее время приобретают значение и вторичные спирты, которые путем оксиэтилирования легко могут быть превращены в первичные спирты и различные неионогенные препараты. Для получения вторичных спиртов разработан метод гидратации олефиновых углеводородов сланцевых смол. В отличие от спиртов, получаемых прямым окислением парафинов в присутствии борной кислоты или гидратацией олефннов в присутствии серной кислоты, спирты, синтезированные С. Файнгольдом, Э. Кийком и Е. Кофкиной, содержат гидроксильную группу лишь во втором и третьем положениях. Представляет также интерес разработанный С. Файнгольдом и Я. Пыерсом способ получения алкилфенилэтиловых первичных спиртов [12].

Благодаря прнсоединению к углеводородному радикалу бензольного ядра и этильной группы, для синтеза можно успешно применять фракции сланцевой смолы, выкипающие до $150^{\circ} \mathrm{C}$.

В связи со значительным расширением области применения ПАВ для технических и бытовых целей, целесообразно увеличить ассортимент синтезируемых ПАВ путем введения в молекулу, между гидрофобной и гидрофильной частями, промежуточных функциональных групп. Синтезируемые С. Файнгольдом и Э. Кийком из сланцевых олефинов новые ПАВ с промежуточными функциональными группами позволяют надеяться, что на базе сланцевых смол может быть организовано производство ПАВ широкого ассортимента.

\section{Стабилизация и очистка углеводородов сланцевых смол}

Фракции смолы. полукоксования, выкипающие до $300^{\circ}$, состоят в основном из углеводородов. Содержание кислородных соединений в них не превышает $25 \%$. Во фракциях, выкипающих до $150^{\circ}$, содержигся до $60 \%$ моноолефиновых углеводородов. С повышением температуры ғ:ипения количество алкенов снижается и во фракшиях $200-300^{\circ}$ составляет примерно 25\%. В настоящее время для синтеза ПАВ применяется фракция, выкипающая в пределах темнератур $150-250^{\circ}$. После обесфеноливания эта фракция содержит до $40 \%$ алкенов. Олефиновые углеводороды имеют преимущественно нормальное строение. Изоолефинов, циклоолефинов и диолефинов в низкокипящих фракциях мало. C повышением температуры кипения фракций содержание их увеличивается и во фракциях, кипящих выше $250^{\circ}$, уже достигает $50 \%$. Циклоолефины и диолефины сравнительно легко удаляются при каталитической стабилизации. Изоолефины при очистке обычно не удаляются. Они представлены структурами, одна боковая цепь которых расположена у второго или третьего углеродного атома. Ароматические углеводороды $\left(25 \%\right.$ от фракции $\left.150-250^{\circ}\right)$ состоят в основном из полиалкилбензолов с короткими алкильными группами. В этой фракции находится до $20 \%$ парафино-нафтеновых углеводородов, представленных преимущественно нормальными парафинами. Наиболее нежелательных компонентов синтеза - нейтральных кислородных и сернистых соеди- 
нений - во фракции $150-250^{\circ}$ содержится до $20 \%$. Нейтральные кислсродные соединения состоят главным образом из алифатических и ароматических кетонов. Из сернистых соединений преобладают производные тиофена и тиофана. Содержание сульфидов, дисульфидов и меркаптанов невысокое. Для эффективного использования в синтезе ПАВ моноолефиновых и парафиновых углеводородов, суммарное содержание которых достигает $60 \%$, вначале необходимо удалить наиболее нестабильные диолефины, циклоолефины и часть нейтральных кислюродных и сернистых соединений. Это достигается каталитической стабнлизацией фракций в присутствии кислотных катализаторов. Катализатор должен способствовать селективной полимеризации циклоолеф:ннов, диолефинов и нейтральных кислородных соединений и не должен воздействовать на моноолефины. При сохранении количества моноолефинов катализатор не должен изомеризовать их двойную связь. После каталитической стабилизации очищенная фракция обычно бесцветна и лишена присущего сланцу неприятного запаха. Удаление при экстракции сильно реакционноспособных соединений позволяет избежать реакции между селективным растворителем и компонентами фракций.

Такие известные способы стабилизации, как алюмосиликатный и сернокислотный, не дают положительных результатов. Первый - из-за сильно изомеризующего и полимеризующего действия на моноолефины, второй - вследствие недостаточного удаления сернистых и кислородных соединений. В химических целях наиболее удобным методом стабилизации средних фракций является жидкофазная полимеризация в присутствии безводного хлористого цинка. Последний, не затрагивая моноолефины и парафины, уводит в комплекс большую часть сернистых и нейтральных кислородных соединений. Циклоолефины и диолефины при этом полимеризуются и при ректификации оказываются в более высококипящих фракциях. С технической точки зрения применение хлористого цинка связано с некоторыми трудностями, так как из-за твердой консистенции комплекса хлористого цинка с кислородными соединениями при комнатной температуре для разложения его требуется специальная аппаратура.

Тем не менее состав фракций сланцевых смол, стабилизированных хлористым цинком, является своеобразным эталоном, который показывает необходимую глубину очистки для получения ПАВ удовлетворительного качества. В дальнейшем хлористый цинк был заменен комплексным катализатором примерно такого состава: $\mathrm{AlCl}_{2} \cdot \mathrm{C}_{6} \mathrm{H}_{4} \mathrm{C}_{n} \mathrm{H}_{2 n+1}$. Этот катализатор в комплексе с соединениями сланцевой смолы имеет жидкую консистенцию и легко отделяется от углеводородов. На моноолефины он действует мягко, т. е. не полимеризует их, хотя несколько изомеризует двойную связь с периферии во внутренние положения. Комплекс хлористого алюминия с ароматическими углеводородами образуется при алкилировании бензола олефинами в синтезе алкиларилсульфонатов. Использование отработанного комплекса выгодно еще и потому, что позволяет извлечь заключенный в нем бензол. Применение отработанного комплекса хлористого алюминия не позволяет достигнуть нужной глубины очистки. Необходима дополнительная сернокислотная очистка или подпитка комплекса свежим хлористым алюминием. Последний прибавляется в количестве до $3 \%$ на исходную фракци!о для предотвращения полимеризации моноолефинов.

Было исследовано также влияние комплексного катализатора $\mathrm{AlCl}_{2} \cdot \mathrm{H}_{2} \mathrm{SO}_{4}$. Он обладает меньшим полимеризующим действием, чем хлористый алюминий, и на моноолефины не влияет. Тем не менее этот 
катализатор оказался неподходящим, так как недостаточно полно удаляет нейтральные кислородные соединения.

Следующим после стабилизации фракций смолы этапом является селективная экстракция.

Экстракция этиленгликолем, этиленхлоргидрином и этаноламинами не привела к положительным результатам ввиду малой селективности этих растворителей. В определенных условиях удовлетворительной селективностью обладает диэтиленгликоль. Хотя регенерация диэтиленгликоля связана с некоторыми трудностями, тем не менее процесс этот налажен в производственных условиях в нефтехимии и может быть использован сланцехимической промышленностью. При обработке керосиновых фракций нефтей диэтиленгликолем в экстракт переходят полиалкилароматические углеводороды. В случае сланцевой смолы в экстракт переходят преимущественно нейтральные кислородные соединения и поэтому достигается бо́льшая селективность. В табл. 1 приведены основные показатели процесса каталитической стаб́лизации и экстракции обесфеноленной фракции сланцевой смолы туннельных печей, выкипающей в пределах температур 150 - $250^{\circ}$.

Таблица 1

Основные показатели стабилизации и экстракции обесфеноленной фракции сланцевой смолы

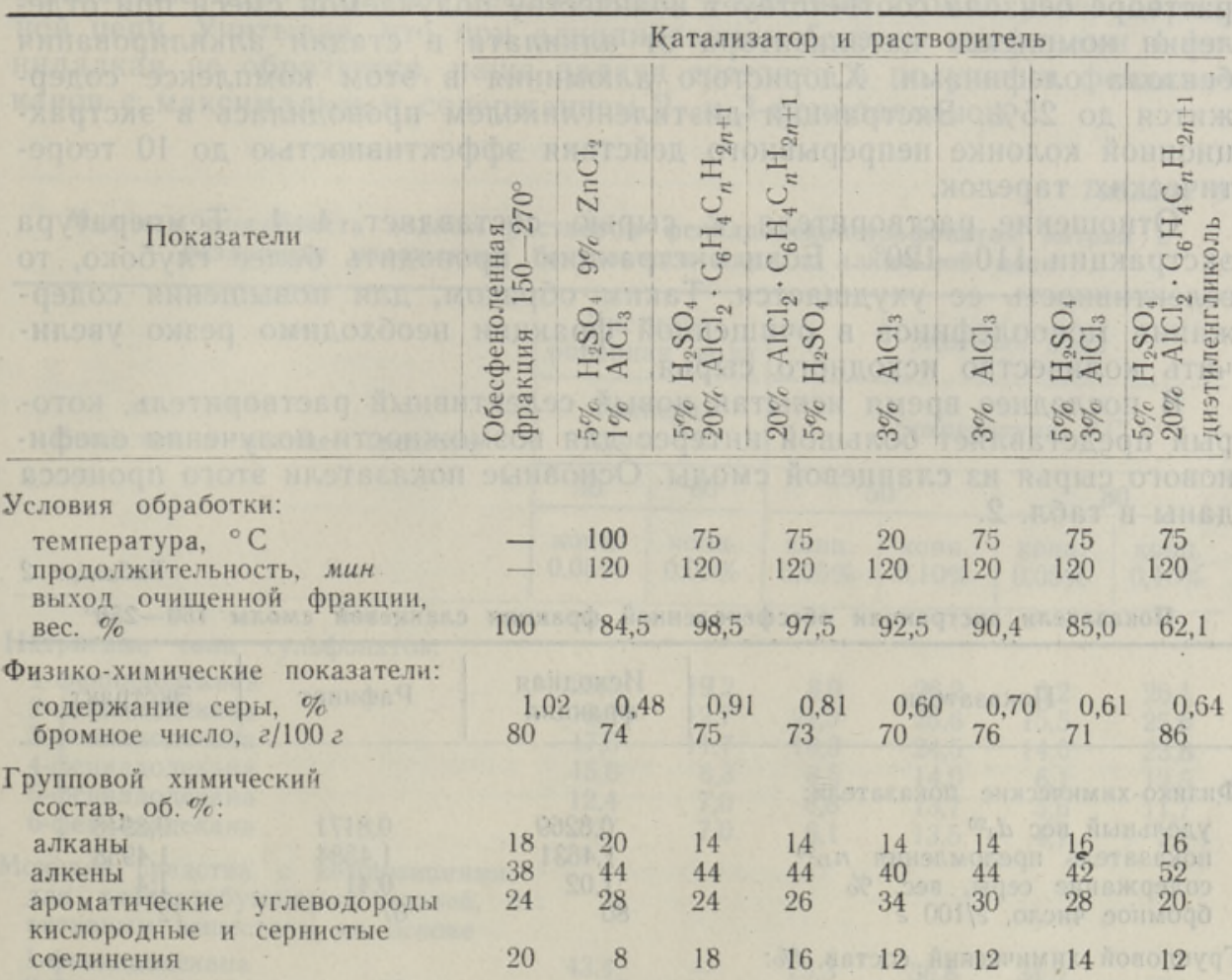

Последовательная обработка фракций 5\% серной кислоты (из расчета на исходную фракцию) и хлористым цинком дает удовлетворительные результаты. Значительно уменьшается количество сернистых и кислородных соединений при относительно высоком содержании во фракции моноолефинов. Приводятся также результаты очистки отрабо- 
танным комплексом хлористого алюминия и серной кислотой при различной последовательности этих процессов. Высокие выходы продуктов в данном случае объясняются тем, что бензол из комплекса переходит в очищаемую фракцию. Действительные выходы на исходное сырье будут на 6-7\% меньше. Одна лишь обработка фракции этими катализаторами не приводит к желаемым результатам. При синтезе из этой фракции алкиларилсульфонатов необходимо увеличить расход хлористого алюминия на алкилирование бензола.

Применение свежего хлористого алюминия (3\%) и последовательная обработка серной кислотой и хлористым алюминием позволяюг, так же как и при использовании отработанного комплекса, несколько снизить содержание сернистых и кислородных соединений и сохранить моноолефины. В последнем столбце табл. 1 приведены данные о применении комплекса процессов для очистки фракции сланцевой смолы, включая последовательную обработку $5 \%$ серной кислоты, $25 \%$ отработанного комплекса хлористого алюминия и экстракцию диэтиленгликолем. Каждый из этих процессов значительно не улучшает показателей качества олефинового сырья, но в сумме достигается определенный положительный эффект. С технической и экономической точек зрения такой комплекс очистки вполне приемлем. Количество отработанного комплекса хлористого алюминия с ароматическими углеводородами в растворе бензола соответствует количеству получаемой смеси при отделении комплекса катализатора от алкилата в стадии алкилирования бензола олефинами. Хлористого алюминия в этом комплексе содержится до $25 \%$. Экстракция диэтиленгликолем проводилась в экстракционной колонке непрерывного действия эффективностью до 10 теоретических тарелок.

Отношение растворителя к сырью составляет 4:1. Температура зкстракции $110-120^{\circ}$. Если экстракцию проводить более глубоко, то селективность ее ухудшается. Таким образом, для повышения содержания моноолефинов в очищенной фракции необходимо резко увеличить количество исходного сырья.

В последнее время испытан новый селективный растворитель, который представляет большой интерес для возможности получения олефинового сырья из сланцевой смолы. Основные показатели этого процесса даны в табл. 2.

Таблица 2

Показатели экстракции обесфеноленной фракции сланцевой смолы $150-250^{\circ}$

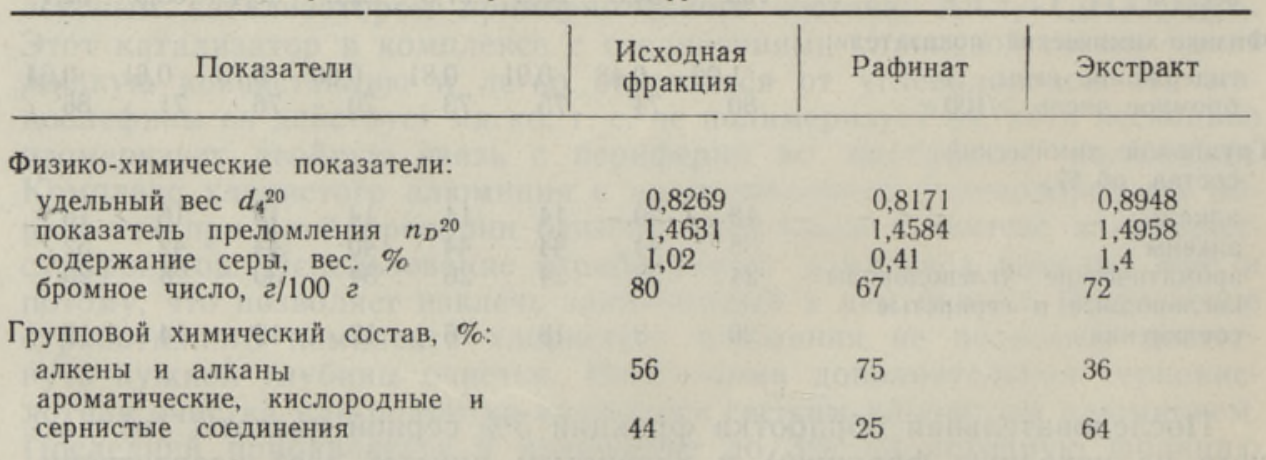

Процесс этот - одностадийный, без предварительной каталитической стабилизации. Судя по бромным числам рафината и экстракта, кроме селективной экстракции в данном случае происходит полимери- 
зация диолефинов и циклоолефинов. Выход очищенной фракции составляет $70,7 \%$. Опыты, проведенные с индивидуальным 1-октеном, показали, что в данном процессе двойная связь не изомеризуется.

\section{Алкилирование бензола алкенами}

Бо́льшая часть выпускаемых мировой промышленностью алкиларилсульфонатов используется для получения моющих средств. Поэтому наиболее важными показателями их качества являются моющая способность и биохимическая окисляемость. Сейчас уже установлено, что лучшими показателями в этом отношении обладают алкиларилсульфонаты с прямоцепочной алкильной цепью [13]. Необходимо было выяснить вопрос о влиянии местоположения бензольного ядра в фенилалканах на показатели качества алкиларилсульфонатов. В связи с противоречивостью данных литературы по этому вопросу $[14,15]$ в нашей лаборатории $\left[{ }^{16}\right]$ были синтезированы все изомеры индивидуальных прямоцепочных фенилалканов (от $\mathrm{C}_{6}$ до $\mathrm{C}_{12}$ ), а во Всесоюзном научноисследовательском институте жиров была определена их моющая способность [15]. Полученные результаты приведены в табл. 3. Они показывают, что моющая способность выше у производных фенилалканов, бензольное ядро которых расположено у крайних атомов углеводородной цепи. Учитывая, что при алкилировании бензола олефинами 1-фенилалкан не образуется, наша задача состояла в получении фенилалканов с максимальным содержанием 2- и 3-фенилалканов.

таблица 3

Моющая способность водных растворов фенилдодекансульфонатов натрия с различным положением бензольного ядра в алкильной цепи

\begin{tabular}{|c|c|c|c|c|c|c|}
\hline \multirow{4}{*}{ Вещество и моющее средство } & \multirow{2}{*}{\multicolumn{2}{|c|}{$\begin{array}{c}\text { Дистилли- } \\
\text { рованная вода } \\
\text { Темпера- } \\
\text { тура, }{ }^{\circ} \mathrm{C} \\
\end{array}$}} & \multicolumn{4}{|c|}{ Жесткая вода } \\
\hline & & & \multicolumn{4}{|c|}{ Температура, ${ }^{\circ} \mathrm{C}$} \\
\hline & 50 & 80 & \multicolumn{2}{|c|}{50} & \multicolumn{2}{|c|}{80} \\
\hline & $\begin{array}{l}\text { конц. } \\
0,05 \%\end{array}$ & $\begin{array}{l}\text { конц. } \\
0,05 \%\end{array}$ & $\begin{array}{l}\text { конц. } \\
0,05 \%\end{array}$ & $\begin{array}{l}\text { конц. } \\
0,10 \%\end{array}$ & $\begin{array}{l}\text { конц. } \\
0,05 \%\end{array}$ & $\begin{array}{l}\text { конц. } \\
0,10 \%\end{array}$ \\
\hline
\end{tabular}

Натриевые соли сульфонатов:

$\begin{array}{lr}\text { 1-фенилдодекана } & 29,5 \\ \text { 2-фенилдодекана } & 19,5 \\ \text { 3-фенилдодекана } & 17,5 \\ \text { 4-фенилдодекана } & 15,6 \\ 5 \text {-фенилдодекана } & 12,4 \\ \text { 6-фенилдодекана } & 7,7\end{array}$

$\begin{array}{rrrrrr}29,5 & 19,2 & 8,0 & 26,2 & 6,2 & 26,1 \\ 19,5 & 12,7 & 21,3 & 25,6 & 15,5 & 25,6 \\ 17,5 & 11,7 & 18,3 & 24,5 & 14,0 & 23,8 \\ 15,6 & 8,3 & 8,5 & 14,0 & 6,1 & 12,5 \\ 12,4 & 7,0 & 8,8 & 13,7 & 5,6 & 11,7 \\ 7,7 & 7,0 & 6,1 & 13,5 & 4,1 & 7,1\end{array}$

Моющие средства с композициями для хлопчатобумажных тканей, с активным веществом на основе

1-фенилдодекана

2-фенилдодекана

3-фенилдодекана

$\begin{array}{llllll}43,4 & - & 25,3 & 36,8 & 34,9 & - \\ 40,8 & - & 31,3 & 36,1 & 34,8 & - \\ 38,7 & - & 28,6 & 34,1 & 30,7 & -\end{array}$

По данным П. Д. Свишера $\left[{ }^{18}\right]$, биохимическая окисляемость алкиларилсульфонатов также зависит от положения бензольного ядра в фенилалканах. Производные 2- и 3-фенилалканов распадаются в водое- 
мах в течение нескольких дней. В тех же условиях производные 5- и 6-фенилдодеканов не распадаются в течение более 10 дней. Поэтому для повышения моющей способности алкиларилсульфонатов и улучшения их биохимической окисляемости процесс алкилирования бензола алкенами необходимо вести в условиях, позволяющих получать наибольшее количество 2- и 3-изомеров и наименьшее - изомеров с внутренним положением бензольного кольца.

Для синтеза алкиларилсульфонатов бензол алкилируется алкенами в присутствии комплекса хлористого алюминия с алкилароматическими углеводородами хлористого алюминия или плавиковой кислоты. Рядом исследователей установлено распределение отдельных изомеров при алкилировании бензола додеценом-1 [9, 17].

В присутствии хлористого алюминия миграция бензольного ядра вдоль алкильной цепи происходит в результате двух реакций: изомеризации двойной связи алкена до присоединения его к бензольному ядру и многократного протекания реакций алкилирования и дезалкилирования.

Наши исследования изомерного состава фенилдодеканов показали, что в присутствии $\mathrm{HF}$ и $\mathrm{AlCl}_{2} \cdot \mathrm{C}_{6} \mathrm{H}_{4} \mathrm{C}_{n} \mathrm{H}_{2 n+1}$ они изомеризуются значительно больше, чем. в случае применения хлористого алюминия $\left[{ }^{19,20}\right]$. Некоторое уменьшение изомеризующего действия хлористого алюминия может быть достигнуто применением его в растворе нитробензола. Изомерный состав фенилдодеканов дан в табл. 4.

Таблица 4

Изомерный состав фенилдодеканов, вес. \%

\begin{tabular}{|c|c|c|c|}
\hline Изомер фенилдодекана & $\begin{array}{c}\text { Безводный } \mathrm{AlCl}_{3} \text {, } \\
\text { темп, } 60^{\circ} \mathrm{C} \text {, моле- } \\
\text { кулярное соотно- } \\
\text { шение бензол : ал- } \\
\text { кен } 5: 1 \text {, скорость } \\
\text { подачи алкена } \\
0,1 \text { моль/4 }\end{array}$ & $\begin{array}{c}\text { Раствор } \mathrm{AlCl}_{3} \text { в } \\
\text { нитробензоле, } \\
\text { темп. } 35^{\circ} \mathrm{C} \text {, моле- } \\
\text { кулярное соотно- } \\
\text { шение бензол : ал- } \\
\text { кен } 9: 1 \text {, скорость } \\
\text { подачи алкена, } \\
0,1 \text { моль/u }\end{array}$ & $\begin{array}{l}\text { Раствор } \mathrm{AlCl}_{3} \text { в } \\
\text { нитробензоле, } \\
\text { темп. } 20^{\circ} \mathrm{C} \text {, моле- } \\
\text { кулярное соотно- } \\
\text { шение бензол : ал- } \\
\text { кен } 12: 1 \text {, } \\
\text { скорость подачи } \\
\text { злкена } 0,014 \text { моль/4 }\end{array}$ \\
\hline $\begin{array}{l}\text {-Фенилдодекан } \\
\text {-Фенилдодекан } \\
\text {-Фенилдодекан } \\
\text { - и 6-Фенилдодеканы }\end{array}$ & $\begin{array}{l}30,4 \\
20,3 \\
17,3 \\
32,0\end{array}$ & $\begin{array}{l}37,6 \\
21,3 \\
13,5 \\
27,6\end{array}$ & $\begin{array}{l}43,53 \\
20,09 \\
12,90 \\
23,48\end{array}$ \\
\hline
\end{tabular}

Таблица 5

Влияние количества катализаторов на выход и изомерный состав додецилбензола

\begin{tabular}{|c|c|c|c|}
\hline $\begin{array}{c}\text { Количество катализа- } \\
\text { тора от додецена-1, } \\
\text { вес. \% }\end{array}$ & $\begin{array}{c}\text { Бромное число } \\
\text { алкилата }\end{array}$ & $\begin{array}{c}\text { Выход монододе- } \\
\text { цилбензола от тео- } \\
\text { ретического, } \\
\text { вес. } \%\end{array}$ & $\begin{array}{c}\text { Содержание 2- и } \\
\text { 3-фенилдодекана, } \\
\text { вес. \% }\end{array}$ \\
\hline
\end{tabular}

5

10 (свежеприготовленный)

10 (несвежий)

15

20

Реакция не пронзошла

$\begin{array}{lcc}0 & 71-72 & 65,4-68,0 \\ 4 & 54,2 & 67,7 \\ 0 & 76,5-80,2 & 63,8-64,6 \\ 0 & 77,8-83,2 & 63,9-71,2\end{array}$


Несмотря на мягкие условия алкилирования, проведением реакции в присутствии хлористого алюминия не удается значительно увеличить содержание в смеси 2- и 3-фенилалканов. Это еще усугубляется тем, что применение раствора хлористого алюминия в нитробензоле в промышленных условиях затруднено. Поэтому в наших дальнейших исследованиях представляло интерес изучить каталитическую активность и изомерный состав модифицированного комплекса хлористого алюминия. Катализатор не гигроскопичен, способ его получения прост и поэтому он пригоден для применения в промышленных условиях. Опыты показали, что оптимальным количеством катализатора является $10 \%$ по весу на исходный алкен. При хранении катализатор теряет активность, и расход его увеличивается до $15 \%$. А это в свою очередь приводит к повышению общего выхода монододецилбензола и содержания 2- и 3-фенилдодеканов в смеси. В табл. 5 приведены данные о влиянин количества катализатора на показатели алкилирования.

Таблица 6

Влияние температуры на показатели реакции алкилирования

\begin{tabular}{c|c|c}
\hline Tемпература & $\begin{array}{c}\text { Выход монодо- } \\
\text { децилбензола от } \\
\text { теоретического, } \\
\text { вес. \% }\end{array}$ & $\begin{array}{c}\text { Содержание 2- и } \\
\text { 3-феннлдодекана, } \\
\text { вес. \% }\end{array}$ \\
\hline 20 & $76,5-84,3$ & $64,6-71,2$ \\
35 & 83,2 & 63,9 \\
50 & $79,8-82,9$ & $59,7-65,0$ \\
60 & 80 & 57,6
\end{tabular}

Алкилирование рекомендуется проводить при температуре $20^{\circ}$, так как повышение температуры не способствует увеличению выхода монододецилбензола, а приводит к уменьшению содержания 2- и 3-фенилдодеканов во фракции монододецилбензола (табл. 6).

Данные о влиянии соотношения бензол : алкен и скорости подачи олефи-

на в реакционную смесь приведены в табл. 7 .

Из табл. 7 видно, что увеличение относительного содержания бензола и уменьшение скорости подачи алкена не приводит к увеличени!о выхода монододецилбензола и к улучшению его изомерного состава.

Влияние условий алкилирования на изомерный состав монофенилдодекана

\begin{tabular}{|c|c|c|c|c|c|c|}
\hline $\begin{array}{l}\text { Соотно- } \\
\text { шение бен- }\end{array}$ & $\begin{array}{l}\text { Скорость } \\
\text { подачи до- }\end{array}$ & Выход от & Положение & $\begin{array}{r}\text { фенильного } \\
\text { цеп }\end{array}$ & ядра в & алкильной \\
\hline $\begin{array}{c}\text { зол : алкен } \\
\text { (весовое) }\end{array}$ & $\begin{array}{c}\text { децена, } \\
2 / \iota\end{array}$ & ского, вес. \% & 5 и 6 & 4 & 3 & 2 \\
\hline $\begin{array}{r}4: 1 \\
10: 1 \\
4: 1\end{array}$ & $\begin{aligned} & 8,33 \\
& 5,0 \\
& 400\end{aligned}$ & $\begin{array}{l}81,1 \\
77,8 \\
78,4\end{array}$ & $\begin{array}{l}6,85 \\
27,6 \\
21,3\end{array}$ & $\begin{array}{c}21,95 \\
8,6 \\
8,5\end{array}$ & $\begin{array}{l}23,6 \\
19,9 \\
22,1\end{array}$ & $\begin{array}{l}47,6 \\
43,9 \\
48,1\end{array}$ \\
\hline & Выход и & и изомерный & состав фени & Ідодеканов, в & ec. $\%$ & Таблица 8 \\
\hline
\end{tabular}

\begin{tabular}{|c|c|c|c|}
\hline & & Катализатор & \\
\hline Название продукта & $\begin{array}{c}\text { безводный } \\
\mathrm{AlCl}_{3}\end{array}$ & $\begin{array}{c}\text { растЕор } \mathrm{AlCl}_{3} \text { в } \\
\text { нитробензоле }\end{array}$ & $\begin{array}{c}\text { модифициро- } \\
\text { ванный комплекс } \\
\mathrm{AlCl}_{3}\end{array}$ \\
\hline
\end{tabular}

Монододецилбензол

2-Фенилдодекан

3-Фенилдодекан

4-Феннлдодекан

5- и 6-Фенилдодеканы
84,3

31,18

19,5

12,94

31,38
70,7

39,16

19,47

10,77

30,60
81,1

47,6

23,6

21,95

6,85

2 ENSV TA Toimetised $\mathrm{K}^{*} \mathrm{G}-268$ 
Для оценки действия модифицированного комплекса хлористого алюминия были проведены опыты в оптимальных условиях (табл. 8).

Смесь моноалкилбензолов, полученных при алкилировании бензола додеценом-1 в присутствии указанных в табл. 8 катализаторов, характеризуется по сравнению с применением хлористого алюминия бо́льшим содержанием 2- и 3-фенилалканов. В этих условиях полимеров образуется меньше, чем при использовании хлористого алюминия. Преимуществом нового катализатора является также то, что он не образует комплекса и после алкилирования его можно отделить фильтрованием или центрифугированием.

\section{Синтез первичных алкилфенилэтиловых спиртов}

В данном разделе рассматривается вопрос о новых путях рационального и эффективного использования легких фракций сланцевой смолы. К настоящему времени разработаны способы синтеза поверхностно-активных веществ из технических нормальных $\alpha$-олефинов, выкипающих в пределах температур 150-250 . Олефины, выкипающие ниже этих температур, для синтеза ПАВ не используются.

Ниже приведены методы и описание синтеза первичных алкилфенилэтиловых спиртов и их оксиэтилированных и сульфатированных производных из фракций сланцевой смолы, выкипающих до $180^{\circ}$.

Спирты из натурального сырья и их производные очень дефицитны и дороги. Стоимость синтезируемых нами препаратов в два раза меньше и они могут служить заменителями спиртов, получаемых из животных жиров. Значительное преимущество этого метода синтеза заключается в том, что он позволяет получать при минимальных технологических изменениях и без дополнительной аппаратуры ПАВ разного типа и с разными свойствами. Такие соединения могут быть использованы в весьма дифференцированной области применения поверхностно-активных веществ.

Практически можно превращать в соответствующие спирты до $50 \%$ сланцевой смолы, используемой в качестве сырья.

Химическая сторона этой работы заключается в алкилировании бензола $\alpha$-олефинами и конденсировании полученных алкилбензолов с окисью этилена. Последняя реакция впервые исследовалась нами $\left[{ }^{12}\right]$. Изучение закономерностей этой реакции имеет и теоретическое значение. Пользуясь некоторыми упрощениями, весь процесс получения ПАВ можно выразить следующими уравнениями:

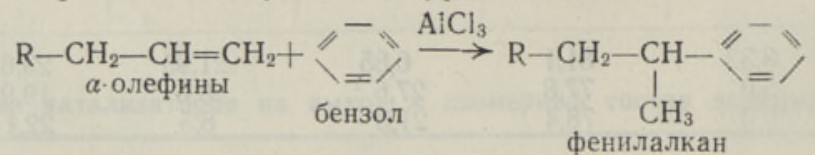

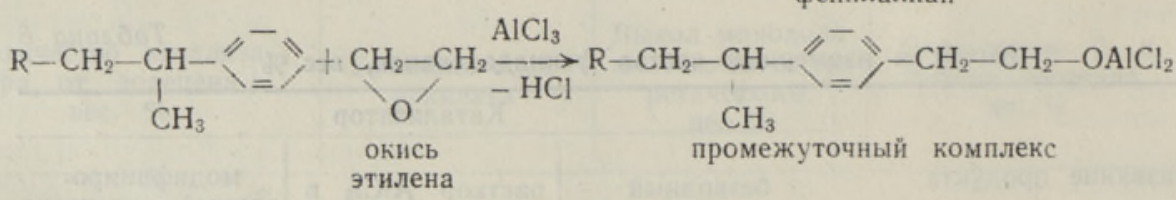

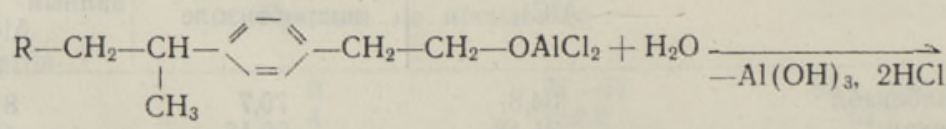

$$
\longrightarrow \mathrm{R}-\mathrm{CH}_{2}-\mathrm{CH}-\mathrm{C}=\mathrm{CH}_{2}-\mathrm{CH}_{2}-\mathrm{OH}
$$

$\mathrm{CH}_{3}$

алкилфенилэтиловый спирт 
В результате дальнейшего оксиэтилирования этих спиртов $\left[{ }^{21}\right]$ получаются поверхностно-активные вещества неионогенного типа:

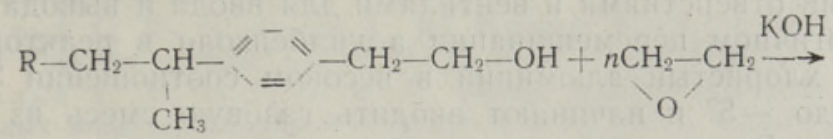

$$
\begin{aligned}
& \rightarrow \mathrm{R}-\mathrm{CH}_{2}-\underset{\mathrm{CH}}{\mathrm{C}}=-\mathrm{CH}_{2}-\mathrm{CH}_{2}-\mathrm{O}\left(-\mathrm{CH}_{2}-\mathrm{CH}_{2}-\mathrm{O}\right)_{n-1} \mathrm{CH}_{2}-\mathrm{CH}_{2}-\mathrm{OH}
\end{aligned}
$$

Сульфатированием оксиэтилированных и неоксиэтилированных алкилфенилэтиловых спиртов можно получить соответствующие вецества ионогенного типа:

$$
\begin{aligned}
& \mathrm{R}-\underset{\mathrm{CH}_{3}}{\mathrm{CH}_{2}-\mathrm{CH}-}-\mathrm{CH}_{2}-\mathrm{CH}_{2}-\mathrm{O}\left(-\mathrm{CH}_{2}-\mathrm{CH}_{2}-\mathrm{O}\right)_{n}-\mathrm{H}+\mathrm{H}_{2} \mathrm{SO}_{4} \rightarrow
\end{aligned}
$$

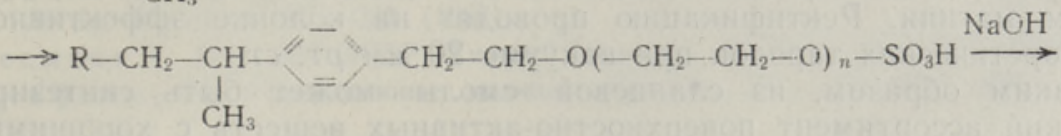

$$
\begin{aligned}
& \longrightarrow \mathrm{R}-\mathrm{CH}_{2}-\mathrm{CH}-\underset{\mathrm{I}}{\mathrm{CH}_{3}}=-\mathrm{CH}_{2}-\mathrm{CH}_{2}-\mathrm{O}\left(-\mathrm{CH}_{2}-\mathrm{CH}_{2}-\mathrm{O}\right)_{n}-\mathrm{SO}_{3} \mathrm{Na}
\end{aligned}
$$

При разработке условий синтеза алкилфенилэтиловых спиртов надо учитывать следующие побочные реакции:

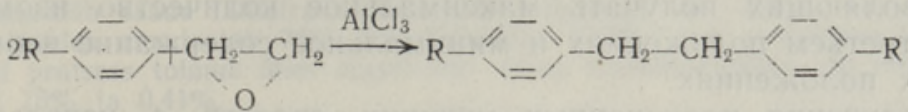

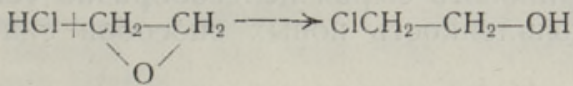

Чтобы избежать реакции (VI), рекомендуется применять более низкий температурный режим. В последней (VII) реакции участвует хлористый водород, выделившийся при реакции (II). Во избежание превращения значительного количества окиси этилена в этиленхлоргидрин, через реакционную смесь вместе с окисью этилена пропускают инертный газ. При этом бо́льшая часть выделившегося хлористого водорода удаляется из реактора вместе с этим газом.

Исходным сырьем для получения алкилфенилэтиловых спиртов могут быть углеводороды, содержащие нормальные $\boldsymbol{\alpha}$-олефины, в том числе выбранная нами фракция сланцевой смолы.

Поскольку выделение нормальных углеводородов из сланцевой смолы и синтез алкилбензолов не представляет собой ничего существенно нового, здесь эти процессы не описаны. Для более глубокого изучения условий синтеза и свойств упомянутых выше новых соединений, нами синтезировался ряд индивидуальных образцов такого типа. Оказалось, что более подходящим методом синтеза является описанный ниже общий метод. 
Процесс оксиэтилирования ведут в охлаждаемом реакторе, снабженном мешалкой, термометром, трубкой для барботирования, соответствующими отверстиями и вентилями для ввода и вывода продуктов.

При энергичном перемешивании алкилбензола в реактор медленно прибавляют хлористый алюминий в весовом соотношении $3: 1$. Смесь охлаждают до $-5^{\circ}$ и начинают вводить газовую смесь из окиси этилена и азота. Вытекающую из специального мерника окись этилена направляют в испаритель и оттуда через ротаметр в смеситель, где с азотом образуется газовая смесь нужной концентрации (1:5 по объему). Барботирование продолжают до тех пор, пока в реакцию пе вступит рассчитанное количество окиси этилена. Молярное соотношение окиси этилена и хлористого алюминия должно быть $1,1: 1$. Температуру реакции надо поддерживать в пределах от -5 до $+5^{\circ}$. Для разложения образовавшегося комплекса в реактор при перемешивании и охлаждении порциями вводят воду. При этом температура не должна превышать $+15^{\circ}$.

После этого смесь алкилбензолов и алкилфенилэтиловых спиртов промывают водой и раствором соды (5-10\%). Сушат эту смесь сульфатом магния. Ректификацию проводят на колонке эффективностью 15 теоретических тарелок при вакууме 20 мм рт. ст.

Таким образом, из сланцевой смолы может быть синтезирован широкий ассортимент поверхностно-активных веществ с хорошими показателями качества.

Основной задачей является улучшение методов очистки олефинового сырья и разработка научно обоснованных способов синтеза конечных продуктов. В области изучения алкиларилсульфонатов задача состоит в нахождении оптимального процесса экстракции олефинов из сложной смеси их с ароматическими и кислородными соединениями.

Алкилирование бензола алкенами должно осуществляться в условиях, позволяющих получать максимальное количество изомеров во втором и третьем положениях и минимальное содержание изомеров во внутренних положениях.

Для получения полноценных моющих средств с использованием синергетического эффекта и максимальным вовлечением в переработку легких фракций олефинового сырья целесообразно ускорить разработку и внедрение в промышленность новых способов синтеза первичных и вторичных спиртов.

\section{ЛИТЕРАТУРА}

1. Кылль А. Т. и Кеель Э. И., Горючие сланцы. Химия и технология, вып. 2 , Таллин, 1955.

2. Файнгольд С. И., Корв М. И., Горючие сланцы. Химия и технология, вып. 2, Таллин, 1956.

3. Файнггльд С. И., Валла с К. Р., Изв. АН ЭССР. Сер. техн. и физ.-матем. наук, 6, № 3,13 (1957).

4. Файнггльд С. И., Химия и технология топлив и масел, № 10, 21 (1959).

5. Кылль А. Т., Кудрявцев И. Б. и Риккен В. А., ГНТК СМ ЭССР, Техн. информация, № 11 (1958).

6. Вооре Х. Ю., Корв М. И., Кудрявцев И. Б., Риккен В. А., Сте панова Г. Г., Томсон Т. В., Файнгольд С. И., Синтетические моющие вещества из сланцевой смолы, под общей редакцией С. И. Файнгольда, Таллин, 1964.

7. Файнгольд С. И., Вооре Х. Ю., Кухи Р. М., Горючие сланцы. Химия и технология, вып. 4, 1961.

8. Файнгольд С. И., Томсон Р. М., Химня и технология топлив и масел, № 7,25 (1962). 
9. Файнгольд С. И., Вооре Х. Ю., ЖПХ, 36, № 11, 2527 (1963).

10. Файнггльд С. И., Корв М. И. и Томсон Т. В., Маслобойная и жировая промышленность, № 9, 23-26 (1963).

11. Файнгольд С. И., Томсон Т. В., Котов А. М., Корв М. И. и др. Бюлл. Горючие сланцы, ГИТИ ЭССР, № 2, 27-36 (1962).

12. Ф а йнгольд С. И., Й ер с Я. Х., Новый способ получения поверхностноактивных веществ, Авторское свидетельство № 181078, выдано 24 окт. 1964 г, Бюлл. изобретений, № 9, год 1966.

13. Файнгольд С. И., Синтетические моющие вещества из нефтяного и сланцевого сырья, М., «Недра», 1964.

14. B a umg arten F. K., Ind. Engng Chem., 35, No. 12, 1348 (1954).

15. Петров А. Д., Никишин Г. И., Неволин Ф. В., Крааль-Осикина Г. А., Орехова Н. В., Юшкевич А. В., Маслобойная и жировая промышленность, № 8, 1958.

16. Nevolin F. W., Kral-Ossykina G. A., Buschujewa E. I, Faingold S. I., Tomson R. M., III. Internationale Vortragstagung über grenzflächenaktive Stoffe, Akademie-Verlag, Berlin, 1967.

17. Ols on A. C., Ind. Engg Chem., 52, No. 10, 833 (1960).

18. S w is her P. D., Chem. Ing. Progr., 60, No. 12, 2274 (1964).

19. Файнгольд С., Корв М., Тээдумяэ В., Изв. АН ЭССР. Химия ${ }^{*}$ Геология, 16, № $3,217-222$ (1967).

20. Л есмент Т., Изв. АН ЭССР. Химия *Геология, 16, № 4, 306-312 (1967).

21. Шенфеллд Н., Неноногенные моющие средства, М., «Химия», 1965.

\section{S. FAINGOLD, M. KORV, H. VOORE, J. JOERS}

\section{SUNTEETILISED PESEMISVAHENDID PŌLEVKIVIÓLIST}

Artiklis antakse ülevaade probleemidest, mis on seoses pōlevkiviōli alkeensete süsivesinike baasil pindaktiivsete ainete tootmisega ja selle teoreetiliste alustega. Näidatakse, et ENSV TA Keemia Instituudis väljatöötatud lähteaine puhastamise kompleksne meetod vőimaldab saada lähtefraktsiooni keemispiiridega $150-250^{\circ} \mathrm{C}$, kus alkeenide ja alkaanide sisaldus moodustab $70 \%$, väävlisisaldus $0,64 \%$; uue selektiivse lahusti kasutamisel, kui protsess toimub ühes staadiumis (ilma eelpuhastuseta), on vastavad väärtused isegi $75 \%$ ja $0,41 \%$.

Esitatakse sünteesil moodustuvate fenüülalkaanide isomeerne koostis ja näidatakse ära selle sōltuvus katsetingimustest, katalüsaatorist jm. Ohtlasi tutvustatakse pindaktiivsete ainetena kasutatavate keemiliste ühendite struktuuri mõju pesemisomadustele ja biokeemilisele oksüdeeritavusele. Käsitletakse ka alküülfenüületüülalkoholide sünteesi probleeme põlevkiviōli olefiinide $\left(\mathrm{C}_{6}-\mathrm{C}_{9}\right)$ baasil ning viimastest mitteionogeensete pesemisvahendite valmistamise küsimusi.

\section{S. FAINGOLD, M. KORV, H. VOORE, J. JOERS}

\section{SYNTHETICAL DETERGENTS OF OIL SHALE}

The authors present a survey of problems connected with the production of surfaceactive substances obtained from alkenes of oil shale, as well as with the theoretical basis of their production. It is shown that the complex method of the rafination of the initial matter, elaborated at the Institute of Chemistry of the Academy of Sciences of the Estonian SSR, allows to obtain an initial fraction with a boiling temperature of $150-250^{\circ} \mathrm{C}$, containing $70 \mathrm{per}$ cent of alkenes and alkanes and 0.64 per cent of sulphur; at the employment of a new selective solvent, with the process being carried out in a single stage (without preliminary raffination), the corresponding figures are even 75 and 0.41 per cent.

The isomeric composition of the phenylalkanes obtained in the course of the synthesis is presented, as well as its dependence on experimental conditions, catalyst etc. Furthermore, studies are effected of the iniluence of the structure of the chemical compounds used as surface-active substances upon the detergent properties and biochemical oxydability. Problems of the synthesis of alkylphenylethyl alcohols obtained from oil shale olefins $\left(\mathrm{C}_{6}-\mathrm{C}_{9}\right)$ are discussed, as well as the questions connected with the production of non-ionogenic detergents from the latter. 